\title{
THE ROLES OF PESANTREN AND MADRASAH IN MODERN SOCIETY
}

\author{
Abdul Mujib \\ Institut Agama Islam Negeri Metro \\ abdulmujib@metrouniv.ac.id \\ Yuyun Yunita \\ Institut Agama Islam Negeri Metro \\ yuyunyunita@metrouniv.ac.id

\section{Syabbul Bachri} \\ Univesitas Islam Negeri Maulana Malik Ibrahim Malang \\ syabbulb@uin-malang.ac.id
}

\section{Abstract}

Pesantren (Islamic boarding schools) have an independent structured learning model. The learning process is carried out informally with the sorogan and bandongan methods, which take place every day. Pesantren and Madrasah (Islamic school) are religious educational institutions managed by organizations or independently to strengthen Islam in society. There are two main strategic roles of Pesantren and Madrasah; to produce a cadre of scholars who study religion and educate students to know science, be skilled, and care about social issues. In modern developments, the demands of the role of Pesantren and Madrasah are increasingly complex. Socio-economic problems that occur in society, such as disintegration, poverty, and moral decline, are increasingly open and rampant in society and can be minimized by the presence of Pesantren and Madrasah. Therefore, Pesantren and Madrasah are expected not only to be able to solve problems related to religious beliefs but also to be involved in solving social problems.

Keywords: Pesantren (Islamic Boarding Schools), Madrasah (Islamic Schools), Islamic Education, Modern Society. 


\section{A. Introduction}

Pesantren (Islamic boarding schools) exist in different circumstances, and it is almost certain that this institution, in showing its simplicity to the diversity of its very simple and distinctive circumstances, never ends. Moreover, all the components in it, such as the Kiai or Ustadh (teachers), and students continuously devote themselves to the continuity of pesantren. But, of course, this cannot be measured by the cutting-edge instruction system guidelines where the teaching staff is paid in material form because of their hard work (Nata, 2001, pp. 100-102).

Teachings that are able to design talented and reliable students can ultimately create graduates who are ready to be used in government agencies. With modernization, the world of pesantren has reacted differently. Some pesantren refuse to mediate with the government because they are considered to undermine the existence of regular pesantren. However, pesantren provide multipurpose reactions by adopting the existing tutoring system informal learning. So that many pesantren have emerged with various types and have called themselves modern pesantren (Masyhud \& khusnurdilo., 2003, p. 111).

\section{B. Roles of Pesantren in Modern Society}

\section{Conceptions of Modern Pesantren}

Since its awakening in the middle of the Walisongo period, pesantren have continued to be the basis for the development of Islam in Indonesia. For a long time, apart from being an educational institution, pesantren also took on social teaching. As a result, pesantren became the control of the surrounding community in responding to the challenges of the times. In this pesantren, Kiai becomes a "channel" for the outside community in the life of the surrounding community.

In the early 70's, some people needed pesantren to provide general lessons for their students (Barnawi \& Arifin, 2017, p. 56). This has led to differences in conclusions among observers of santri (students) and pesantren. Some argue that pesantren as special and typical educational institutions must maintain the traditional system. Even so, another 
conclusion needs pesantren to start adopting a social and instructive component from the outside (Madjid, 1985, p. 126).

After a long journey, at the beginning of the 20th century, the unused components took the form of classical teaching that began to enter the pesantren, usually, as one of the consequences of developing formal schools established by the Dutch government through political ethics, which implement a classical teaching framework.

Currently, pesantren in the provision of education and teaching can be classified into three forms, namely (Hasbullah, 1996, p. 45):

a. Pesantren are institution that adhere to Islamic teachings, and educational teachings, which are generally provided in a nonclassical manner and students often live in huts or dwellings within the pesantren.

b. Pesantren is an institution that gives education and Islamic teachings, whose students are not provided with facilities in the pesantren complex but live scattered around the corners of the city around the pesantren. The implications and methods of teaching are given using the weton framework, that is to be precise students come in droves at certain times to learn in pesantren.

c. Pesantren is currently a joint institution between a framework and pesantren that provides education and teachings of Islamic Religion using bandungan, sorogan, or wetonan system, in which students are given lodgings commonly referred to as modern pesantren that meet the criteria for non-formal education and administration of formal education. Both madrasah (Islamic school) and schools are opened at different levels.

Meanwhile, in terms of regulations, the Minister of Religion of the Republic of Indonesia, in power number 3 of 1979 classified the types of pesantren into four, they are:

a. Pesantren type A, which is a place where students consider and live in an pesantren environment with the education that takes place in a traditional manner (wetonan or sorogan framework). 
b. Pesantren type B, which provides classical education, and teaching by Kiai is an application that is given at certain times. Santri live in an pesantren environment.

c. Pesantren type $\mathrm{C}$, to be precise, pesantren is a place to live while students consider outside (inside madrasahs or other open schools), Kiai as manager and guide for santri.

d. Pesantren Type D, which organizes the pesantren bungalow system as well as the school or madrasah framework.

From the four types of pesantren above, it appears that such as type A may not be included in the category of modern pesantren, even though in a modern system, it is not simple to classify them into types of pesantren called salafiyah (traditional) and khalafiyah (modern). This is because at present many pesantren that are claimed to be salafiyah turns out that there are also logical strategies that are considered more complete than khalafiyah.

Modern pesantren seek to combine traditionality and educational innovation. The classical model of the formal education system (educating in the classroom) and coordinating the curriculum adopted with certain changes. The polarity of religious knowledge and general science is also removed. These two areas of information are equally instructed but with a more powerful level of religious education. The instruction framework used in the modern pesantren is called the Mu'allimin system.

According to Barnawi, currently, pesantren have undergone significant transformations both in the education system and in organizational elements (Barnawi \& Arifin, 2017, p. 56). These pesantren have been supervised with a very neat and clean administration. The teaching system is actualized in the same area of obedient teaching and general teaching with the dominance of English and Arabic. Since the mid-1970s, pesantren have established and received formal education as a portion of pesantren, starting from basic education, additional education, and even higher education, and they have actualized management principles.

With the existence of "boundary" between salafiyah and khalafiyah, then, as stated by M. Sulthon Masyhud and M. Khusnurridlo, that we can 
see the difference between salafiyah and khalafiyah pesantren by what they contain. (Masyhud \& khusnurdilo., 2003, p. 76).

\section{Characteristics of Modern Pesantren}

With changes in both the culture, system, and values that exist within pesantren, now pesantren known as salafiyah (traditional) has now changed to become khalafiyah (modern). This change is a reaction to the reaction given by pesantren to this current of transformation, so that in the framework and culture of the pesantren there are drastic changes, for the cases of:

a. Changes in the teaching framework from a person (sorogan) to the classical framework at that time we are known as a madrasah (Islamic school).

b. Provide general information while maintaining religious and Arabic language information.

c. Expanding the components of pesantren learning, for the ability to illustrate in accordance with the capacities and needs of the community, Islamic expression.

d. Graduates of pesantren are given shahadah (recognition certificate) as a sign of completion of the pesantren and certain shahadah whose respect is the same as an affirmation of the state.

\section{The Purpose of Pesantren Education}

By relying on Allah SWT, Kiai begin their pesantren education with a sincere intention to enforce his sentence, supported by simple and limited infrastructure. Relevant to the spirit of simplicity, the purpose of education is to create and develop a Muslim personality, namely a personality who believes and is devoted to Allah SWT, has a noble character, is beneficial to society, as a public servant, is independent, free and steadfast in personality, spreads religion, or enforces religion. Islam and the glory of Muslims in the midst of society ('izz al-Islam wa almuslimin), and love knowledge in order to develop Indonesia's personality.

The purpose of the pesantren teaching system is to prioritize obtaining useful knowledge rather than pursuing material things. 
Through the Ministry of Religion of the Republic of Indonesia, the government has standardized religious education in pesantren. In the intensification workshop for the development of pesantren on 2-6 May 1978, the objectives of the pesantren were: to foster citizens to have a Muslim personality according to the teachings of Islam and instill this sense of religion in all aspects of life as people who are useful for religion, society, and nation (Setyaningsih, 2016, pp. 167-183).

\section{Roles of Madrasah in Modern Society}

\section{Madrasah in the Context of National Education}

The hallmark of madrasah is more than just the presentation of religious subjects. That is, this characteristic is not only presenting Islamic religious subjects in madrasah institutions but, more importantly, the embodiment of Islamic values in the totality of madrasah life. The atmosphere of the madrasah institution that contains this characteristic contains the following elements: a) The embodiment of Islamic values in the entire life of the madrasah institution; b) Actualizing moral life; c) Management that is professional, open, and plays an active role in society (Akhwan, 2008, pp. 41-54).

With such a madrasah atmosphere, it gives birth to a madrasah culture which is the identity of the madrasah educational institution. However, the autonomy of madrasah educational institutions can only be maintained if madrasah retain their basis as community-based education with the needs of the new democratic Indonesian society.

The existence of madrasah as a national education sub-system needs to be maintained and developed. Madrasah education is able to make a significant contribution if it is accompanied by modern and Islamic methodologies. For that, we need teachers who are able to educate and teach with a methodology that is in accordance with the challenges of the times of the students.

\section{Modern Madrasah in Global Competition}

Globalization is a global process due to advances in science and technology, especially in telecommunications and transportation. Globalization brings positive and negative impacts on the interests of the 
nation and the State. Positive impact, for example, it is easier for us to obtain information from outside and can help us find new alternatives in solving the problems we face. The negative impact of it is the inclusion of information that we do not need or can even destroy the value order that we have adopted and a symptom that children from the upper levels of society have the opportunity to learn at the best schools and are able to study in quality universities, both in terms of country and abroad. Meanwhile, the children from the lower class did not get these kinds of things; many of them even dropped out.

In the context of preparing students for the changing times due to globalization, Madrasah have a very important role. The success of madrasahs in preparing students to face the challenges of a more complex future will produce graduates who have a competitive advantage and become leaders of the ummah, national leaders who help determine the direction of the development of this nation.

In order for madrasah graduates to have a global perspective, which sees that the entire face of the earth belongs to Allah as a place to serve, madrasahs must also have a global perspective. Therefore, madrasah must prepare students to continue their studies and work abroad. For this reason, mastery of foreign language skills (especially Arabic and English) becomes very important, as well as the introduction of foreign cultures and nations.

With graduate competencies that include attitudes, knowledge, and skills in accordance with agreed national standards, madrasah are generally community-based education, having a strong basis, because they come from and for the people, and have a value of excellence that is humanistic and divine in nature, namely an educational process that pays more attention to aspects of human potential as social beings and religious creatures, 'abdullah and khalifatullah, as well as individuals who Allah gives the opportunity to develop their potentials.

\section{Preparing Quality, Responsive and Adaptive Madrasahs}

According to Danim, the quality of education is not only measured by the quality of the education output as a whole (education outcomes) but is also related to the context in which the quality is attached and how 
much additional requirements are needed for it (Danim, 2008, p. 80). For example, a graduate of Madrasah Aliyah to occupy the world of work does not need to receive additional training before providing services in his workplace, meaning that he is a graduate with higher quality than those who still have to undergo training.

The quality of education can also be measured by the size of the capacity of education services to meet customers' needs in terms of the number of sacrifices required for this, such as costs incurred by the community or government, length of study, and indirect costs.

The challenges faced by madrasahs in carrying out their mission are not small. This is due to:

a. The change in the orientation of community education. Preparation for the industrialization era has caused the orientation of public education to change from "learning to seek knowledge" to "studying as preparation for getting a job." This is a result of the increasing spread of Western education in Indonesia, which from the start was indeed oriented towards "getting a job." This trend has swept the world because it is this Western model of education adopted in almost all countries in the world. Moreover, this change in orientation makes public schools, which provide more general education, more attractive to parents than pesantren or madrasah.

b. General education in the eyes of the community, in general, takes precedence over religious education. This is reflected in the 1994 curriculum, where the percentage of religious education has been reduced. Madrasah, which initially prioritized religious studies over general subjects, often scrambled to catch up with public schools in the field of general subjects.

c. The quality of education services provided by the majority of the madrasah is still considered to be lower than the education services provided by some private schools, let alone state ones. The causes of this lack of quality are various: due to the lack of 
d. good management (management) of education, poor quality of teaching staff, and lack of day-to-day operational funds.

Substantially, morality is a rule, good and bad guide, sympathy for the phenomena of the life and livelihood of others, and justice in acting. A moral human means a man who becomes a whole person physically and spiritually, and knows how he should act and how he should act to become an ideal person in the eyes of society. They are people whose daily lives benefit individuals and members of society in general. This problem is the focus of the attention of madrasah in maintaining the morality of students.

\section{Strategic Role of Pesantren and Madrasah in Modern Society}

It is known that the conventional role of pesantren is to carry out the process of transferring Islamic religious knowledge, producing ulama' (Islamic scholars) cadres, and maintaining tradition. In modern developments, pesantren, madrasah, and schools face new challenges, in which the three Islamic institutions cannot escape the modernization process. The impact of modernization, at least, affects these three Islamic institutions from various aspects. Among them are the institutional system, the orientation of the Kiai-santri relationship, and the leadership and role of institutions. The orientation of the roles of those institutions is strongly influenced by internal factors of the pesantren, especially the view of their Kiai, and external factors that are developments and demands of the times (call it the influence of globalization). Observing the increasingly widespread development of globalization, we can be sure that many people "believe" the role of pesantren, madrasah, and schools in spreading Islam in this archipelago. However, not many of them know when the pesantren was firstborn. Historians also disagree about the beginning of the pesantren. The existence of pesantren, madrasah and schools cannot be separated from the spread of Islam in Indonesia.

In modern developments such as today, the demands of the role of pesantren are increasingly complex. Socio-economic problems that occur in society, such as disintegration, poverty, moral decline, are increasingly open and rampant in society. Pesantren are expected not only to be able to 
solve problems related to religious ideology but also to be involved in solving these social problems.

There are two main strategic roles of pesantren, madrasah, and schools, namely to produce a cadre of scholars who study religion and at the same time know, are skilled, and care about social issues. The role of pesantren like this is actually no stranger to the world of pesantren because the world of pesantren already knows very well that every human being who wants to be successful must master the knowledge and be innovative as the message of the Prophet Mohammed PBUH regarding work ethics in the following hadith: "From Rifa' ah ibn Rafi', that Rasulullah PBUH was once asked which business was the best. He answered: that is someone's business with his own hands and all buying and selling which are clean" (al-Bukhari). The next message of the Prophet that is no less important is "whoever wants to be successful in world affairs must have the knowledge, just as he wants to be successful in the hereafter, and whoever wants to obtain both of them, for him also master the knowledge of the world and the hereafter." (Haningsih, 2008, pp. 27-39).

Pesantren begin by setting the right vision and mission (goals), namely to produce cadres who are experts in religion and qualified in social affairs, then work together with the government to build partnerships to formulate policies and development programs for the future educational institutions. Simple suggestions, for example, by referring to the formal standardized school quality system and industrybased managerial aspects (by still referring to the Qur'an and Hadith).

\section{E. Conclusion}

Pesantren are the oldest Islamic educational institution that has functioned as one of the strongholds of the Muslim community, a center for preaching, and a center for the development of the Muslim community. Informally, pesantren in Indonesia has functioned as an institution that shapes the character and personality of students. As an Islamic educational institution, pesantren has five main elements: the boarding house (pondok; asrama) where the students stay, the mosque, the students, teaching classical books (kitab kuning), and Kiai. Madrasah are a 
form of development from the traditional Islamic education model, namely pesantren. The presence of madrasah is one of the efforts to reform Islamic education in Indonesia. So it is not wrong to say that madrasah are modern educational institutions in the middle of pesantren as one of Indonesia's educational institutions.

\section{BIBLIOGRAPHY}

Akhwan, M. (2008). Pengembangan Madrasah sebagai Pendidikan untuk Semua. El-Tarbawi, 1(1), 41-54.

Barnawi \& Arifin, M. (2017). Sistem Penjaminan Mutu Pendidikan Teori dan Praktek. Yogyakarta: Ar-Ruzz Media

Danim, S. (2008). Visi Baru Manajemen Sekolah. Jakarta: Bumi Aksara.

Haningsih, S. (2008). Peran Strategis Pesantren, Madrasah dan Sekolah Islam di Indonesia. El-Tarbawi, 1(1), 27-39.

Hasbullah. (1996). Kapita Selekta Pendidikan Islam. Jakarta : Rajawali Press.

Ismail SM., dkk. (2002). Dinamika Pesantren dan Madrasah. Yogyakarta: Pustaka Pelajar.

Madjid, N. (1985). Bilik-Bilik Pesantren. Jakarta: P3M.

Masyhud, Sulthon, M dan Khusnurdilo, M. (2003) Manajemen Pondok Pesantren.Jakarta: Diva Pustaka

Nata, A. (2001). Sejarah Pertumbuhan dan Perkembangan Lembaga-Lembaga Pendidikan Islam di Indonesia. Jakarta : RajaGrafindo Persada.

Noor, M. (2006). Potret Dunia Pesantren. Bandung: Humaniora.

Setyaningsih, R. (2016). Kontinuitas Pesantren dan Madrasah di Indonesia. al-Ta'dib, 11(1), 167-183. 